\title{
Experimental Research on Schools as Learning Organisations: The Case of Romania
}

GABRIELA ALINA PARASCHIVA

Politehnica University of Timisoara, Romania

gabriela.paraschiva@student.upt.ro

ANCA DRAGHICI

Politehnica University of Timisoara, Romania

anca.draghici@upt.ro

The 'learning organization' is one of the organizational models developed by the academic and business environment to provide solutions to the need for companies to adapt and survive, which knew over time numerous extensions, from being defined in relation to business organizations, to be linked to non-profit organizations - hospitals, public administration and even schools and universities. Following the 'school as leaning organization' (sLO) concept and model proposed by Kools and Stoll (2017), the present paper explores the question of to what extent the keycharacteristics of learning organizations already exist in schools in Romania. It is based on previous results of a theoretical approach which showed that a slight starting baseline could be given by the performance indicators and descriptors identified as being correlated with dimensions and key-characteristics of the OECDUNICEF'S SLO model. The present approach in an experimental one, at a sample of 238 urban and rural schools externally evaluated in the first semester of the school year 2018-2019 and the results highlight that the minimum levels of incidence of several key-characteristics of SLO's varying between $30.67 \%$ and $73.10 \%$. The limitation of this paper is given by the fact that the data were collected from the external and internal evaluation of schools, in order to determine the level of educational services offered, means not specifically devoted to identifying sLo characteristics.

Key words: school as learning organization, levels of incidence of key-characteristics, external-internal evaluation https://doi.org/10.26493/1854-4231.14.257-270

\section{Introduction}

In attempting to provide solutions to the need for companies to adapt and survive, in the early 9o's the academic and business environment developed several theoretical new organizational models, 
among which the 'learning organization.' This concept and model gained wide recognition when Peter M. Senge published in 1990 the work The Fifth Discipline: The Art and Practice of the Learning Organization, with five core 'learning disciplines' - personal mastery, mental models, creation of a common vision and team learning, systemic thinking.

The learning organization concept and model knew over time numerous extensions, from being defined in relation to business organizations, to be linked to non-profit organizations - hospitals, public administration and even schools and universities. The last approach on schools direction was made by Kools and Stoll (2017), which proposed a model for re-conceptualizing them as a learning organization focusing on seven action-oriented 'dimensions' (based on the model promoted by Watkins and Marsick): (1) developing and sharing a vision centered on the learning of all students; (2) creating and supporting continuous learning opportunities for all staff; (3) promoting team learning and collaboration among all staff; (4) establishing a culture of inquiry, innovation and exploration; (5) embedding systems for collecting and exchanging knowledge and learning; (6) learning with and from the external environment and larger learning system; (7) modelling and growing learning leadership. This last approach was complemented with key - characteristics (key features) for each of the seven directions of action through the guide 'What Makes a School a Learning Organisation? A Guide for Policy Makers, School Leaders and Teachers' (OECD 2016), therefore offers the possibility to be measured and established both the starting level and the degree of transformation after a certain period and a series of taken steps.

Considering that between 2009 and 2018, the following phenomena occurred at national educational level: (1) a general decrease in the school population (by 17\% till 2016, compared to 2006), (2) the transfer of the last year of kindergarten to primary education (along with reshaping both their curriculum), (3) the gradual transformation of arts and crafts schools into technological high schools, followed, from 2014, by a strong return to professional schools, (4) a massive reorganization of the school network (many public schools losing their decisional and administrative independence, being transformed into structures of other schools and destroying organizational culture of both, the receiving and the received school) and (5) the constant decrease of public expenditure in education (from $5.76 \%$ of total expenditures in 2009 , to $3.76 \%$ of total expenditures in 2017), a considerable pressure was felt at the Romanian educational

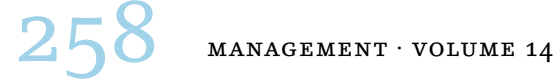


system, with repercussions on the efficiency of the school organizations - a research entitled 'A Study of the Evolution of Educational Efficiency: Romanian case' carried out in 2017 on a representative sample of 2956 schools, highlighted, among other things, that for the $2014-2017$ period, $64.7 \%$ of them registered negative evolutions of the efficiency index, $15.6 \%$ had a steady evolution and only $19.7 \%$ had positive evolutions of the efficiency index (Paraschiva et al. 2017, 6-7).

In this context, an approach on schools al learning organizations (SLO) at the Romanian educational system level has been developed, both theoretical and experimental, aiming to provide a starting point on the necessity and opportunity of implementing it. The present paper presents the final part of the general approach on sLo model proposed by OECD (2016) and Kools and Stoll (2017), Romanian case - an experimental research developed on a sample of 238 rural and urban schools externally evaluated in the first semester of the school year 2018-2019.

\section{Literature Review}

The advantages for the implementation of the 'learning organizations' concept and model, according to Sarder $(2016,10)$, derive from the following:

1. The organization gets always to be supplied with new ideas and information (coming from science and technology, the environment, human resources development etc.);

2. Learning as a process of the whole organization makes new ideas and information spread and transferred to all (organizational) levels from the lowest to the top (top management) and transposes them into action;

3. Learning not only leads to the improvement of the product and/or services offered, but also to a growth/development of the working environment that adapts more easily to the challenges, responds more quickly to different situations/problems and becomes more efficient;

4. Organizational behaviour changes as a result of the development of an environment based on openness and trust, changes are perceived as part of the process of improvement and development, and organizational culture becomes one of continuous improvement;

5. The organization is more likely to attract, retain and motivate the best employees. 
However, almost three decades after initiation, a modest progress has been made in the implementation of the 'learning organization' model: (1) either due to the multitude of approaches (there is not only one standard model, no single conversion path), (2) or due to the lack of measurement and assessment tools that accompanies proposed models (tools capable of diagnosing the current organizational state of art and of guiding change in his core dimensions/elements), (3) or because the proposed models addressed exclusively top management (leaving the middle management, where concrete activities are carried out, discovered), (4) or because transformation and results are not immediate (requiring time and effort at all levels, mentality changes and management commitment).

Regarding Romania, the general concept and model of learning organization have very few approaches that exceed the theoretical level, using a specific assessment methodology and measurement tools in order to determine incidence of certain key-characteristics, but none of them directed towards schools in pre-university level. Among them are:

1. One who was directed towards the public administration - an exploratory study on 26 County Councils (out of 41 ) for diagnosing the current state of art in relation to a learning organization, using the model and instrument proposed by Garvin, Edmondson and Gino (Giura 2012); according to the results, the 26 Romanian County Councils are learning organizations only in terms of leadership that encourages learning (for 'learning environment' and 'learning processes,' the findings revealed that the County Councils act like learning organizations in a very small degree).

2. One who was directed towards business - a survey on 20 large pharmaceutical companies controlling about $80 \%$ of the Romanian sales market and 6 SMEs pharmaceutical companies, over the elements (dimensions) that define a learning organization, using the models originally developed by Senge (1990) and later improved by Watkins and Marsick (1993) (Bordeianu et al. 2014); according to the results, large companies obtained higher scores on most dimensions ('systems thinking,' 'shared vision,' 'organizational culture and learning environment' and 'knowledge transfer') while some dimensions (such as 'teamwork and collaboration' and 'leadership and employee empowerment') have slightly higher scores in case of SMEs.

First part of the general approach on sLo model proposed by овCD (2016) and Kools and Stoll (2017), Romanian case (the theoretical 
approach and its results) showed that the implementation of this model:

1. Could be on opportunity to embrace focus on students from organizational side, complementing the national project CRED ('Relevant curriculum, open education for all' - 'Curriculum relevant, educatie deschisa pentru toti,' funded by the ESF with 42 million euro, to support the reform of the current school curricula) which embrace focus on students from teachers side; these two demarches can be developed in synergy to enhance studentfocus.

2. Could rely on a slight starting baseline given by the performance indicators and descriptors which were identified as being correlated with dimensions and key-characteristics of the OECD's (2016) and Kools and Stoll's (2017) SLo model (table 1 presents this correlation).

The final part of the general approach on sLo model proposed by OECD (2016) and Kools and Stoll (2017), Romanian case - the experimental research - is based on the results of the external and internal evaluation (self-evaluation) on a sample of 238 rural and urban schools in relation to 43 performance indicators (including descriptors) for quality assessment and quality assurance in pre-university education provided in the Romanian Government Decision no. 1534 (Guvernul României 2008). Both types of assessments (external and internal) are carried out on the same descriptors and indicators and on the same five-steps orderly quality scale, in order to process the data being realized their equivalence on a quantitative scale, with points: o - unsatisfactory (means that the minimum/basic requirements are not met), 1 - satisfactory (means that the minimum/basic requirements are met), 2 - good (means that at least one performance descriptor is reached), 3 - very good (means that all performance descriptors are reached), 4 - excellent (means that the organization has proven to achieve all performance descriptors and in addition has developed its own descriptors, in line with the context in which it operates and the specificity of its educational services, own descriptors which are shown to have been achieved).

\section{Research Methodology}

DATA COLLECTION AND SAMPLE

The data collection process for this research relies in 238 public reports from the first semester of the 2018-2019 school year (postsecondary schools - 1, colleges and high schools - 54, gymnasium 
TABLE 1 Correlations between Underlying Characteristics of the oECD's (2016) and Kools and Stoll's (2017) SLo Model and Performance Indicators That Are Used at Romanian National Level in Order to Establish the Quality of the Educational Services

\begin{tabular}{|c|c|c|}
\hline \multicolumn{2}{|c|}{ Dimension/characteristics } & \multirow[b]{2}{*}{$\begin{array}{l}\text { Performance indicators (and descriptors) } \\
\text { Indicator 3o: Scientific activity of teachers. Teachers } \\
\text { participation in the scientific research activity car- } \\
\text { ried out by the school or at local, regional, national } \\
\text { or international level it has grown in number and } \\
\text { percentage }\end{array}$} \\
\hline 2nd & $\begin{array}{l}\text { Professional learning } \\
\text { connects work-based } \\
\text { learning and external } \\
\text { expertise }\end{array}$ & \\
\hline & & $\begin{array}{l}\text { Indicator 31: Methodological activities of teachers. } \\
\text { Teachers participation in the methodological activ- } \\
\text { ities carried out at territorial level - with demon- } \\
\text { stration activities, presentations etc. - it has grown } \\
\text { in number and percentage. }\end{array}$ \\
\hline & & $\begin{array}{l}\text { Indicator 36: Professional development of staff. The } \\
\text { application in teaching activities of the participa- } \\
\text { tion's results in continuous training and profes- } \\
\text { sional development programs is systematically } \\
\text { monitored. The application in teaching activities } \\
\text { of the participation's results in methodological and } \\
\text { scientific activities is systematically monitored. }\end{array}$ \\
\hline & $\begin{array}{l}\text { Professional learning } \\
\text { is based on assessment } \\
\text { and feedback }\end{array}$ & $\begin{array}{l}\text { Indicator: } 36 \text { Professional development of staff. Ob- } \\
\text { serving the current activity and the feedback re- } \\
\text { ceived from the relevant beneficiaries are used for } \\
\text { the review of the professional development plans. }\end{array}$ \\
\hline & & $\begin{array}{l}\text { Indicator 39: Teaching staff evaluation. The assess- } \\
\text { ment of the teaching staff is based on feedback } \\
\text { from relevant stakeholders. The assessment of the } \\
\text { teaching staff includes recommendations for fur- } \\
\text { ther development. }\end{array}$ \\
\hline
\end{tabular}

Continued on the next page

schools - 139, primary schools -2 , kindergartens -30 , school sports clubs -3 , clubs for children -5 , inclusive education centres -4 ) regarding the level of educational services provided, 124 organizations being from the urban area and 114 organizations being from rural area. The distribution of these 238 schools by type of services provided and by residence area do not reflect the situation at national level, their list being generated by the County Schools Inspectorates (due to the fact that they never went through a regular external evaluation process).

MEASUREMENTS

For the first level of the analysis, they were determined for ten performance indicators developed at national level (presented in table 
TABLE 1 Continued from the previous page

\begin{tabular}{lll}
\hline Dimension/characteristics & Performance indicators (and descriptors) \\
\hline 5th & $\begin{array}{l}\text { Systems are in place to } \\
\text { examine progress and } \\
\text { gaps between current } \\
\text { and expected impact }\end{array}$ & $\begin{array}{l}\text { Indicator 28: Evaluation of pupils' school results. } \\
\text { Each teacher can describe for each group and stu- } \\
\text { dent the strengths and weaknesses regarding the } \\
\text { achievement of the curricular objectives. }\end{array}$ \\
\hline $\begin{array}{ll}\text { The school develop- } \\
\text { ment plan is evidence- } \\
\text { informed, based on }\end{array}$ & $\begin{array}{l}\text { Indicator } 37 \text { : Revision of the educational offer and of } \\
\text { the development plan. The benchmarking is used }\end{array}$ \\
$\begin{array}{l}\text { learning from self- } \\
\text { assessment, and up- } \\
\text { dated regularly }\end{array}$ & $\begin{array}{l}\text { ment plan. The staff and relevant stakeholders are } \\
\text { involved in reviewing the educational offer and the } \\
\text { development plan. }\end{array}$ \\
$\begin{array}{ll}\text { The school regularly } \\
\text { evaluates its theories of } \\
\text { action, amending and }\end{array}$ & $\begin{array}{l}\text { Indicator } 34: \text { Existence and implementation of insti- } \\
\text { tutional self-evaluation procedures. The results of } \\
\text { updating them as nec- } \\
\text { essary }\end{array}$ & $\begin{array}{l}\text { self-evaluation and external evaluation are used } \\
\text { and improvement activities and procedures. }\end{array}$ \\
\hline
\end{tabular}

Continued on the next page

1) the following: (1) the average external assessment scores (as a simple arithmetic mean of the results obtained by the 238 schools in the external evaluation), (2) the average internal assessment scores (as a simple arithmetic mean of the results provided by the 238 schools in the external evaluation) and (3) the average score's differences between internal and external prospects, to see to what extent these two are close for the ten targeted performance indicators; positive values mean that the result of self-evaluation is higher than the external evaluation (so school organizations have been overrated) and negative values mean that the result of self-evaluation is lower than that of external evaluation (so school organizations have been underestimated).

For the second level of the analysis, were introduced: (1) the dispersion for each set of values (self-evaluation and external evaluation) and for each of performance indicators (as a synthetic indicator of variance, which provides information on the degree of scattering of the elements relative's to the average, considered as a central trend) and (2) the $\mathrm{z}$ parameter test (two-tail) for comparing the averages of sample values (self-evaluation and external evaluation) per indicator. Therefore, parametric bilateral tests were performed to compare the means of the sample values (238 sample values for self-evaluation and 238 sample values for external evaluation), having as background: the hypothesis Ho (or the null hypothesis) - the values compared do not differ between them (in other words, the 
TABLE 1 Continued from the previous page

\begin{tabular}{|c|c|c|}
\hline \multicolumn{2}{|c|}{ Dimension/characteristics } & \multirow{2}{*}{$\begin{array}{l}\text { Performance indicators (and descriptors) } \\
\text { Indicator 3: The existence and functioning of the } \\
\text { internal and external communication system. The } \\
\text { school systematically communicates with parents } \\
\text { and other stakeholders. }\end{array}$} \\
\hline 6 th & $\begin{array}{l}\text { The school is an open } \\
\text { system, welcoming ap- } \\
\text { proaches from potential } \\
\text { external collaborators }\end{array}$ & \\
\hline & \multirow[t]{3}{*}{$\begin{array}{l}\text { The school collaborates } \\
\text { with parents/guardians } \\
\text { and the community as } \\
\text { partners in the educa- } \\
\text { tion process and the or- } \\
\text { ganization of the school }\end{array}$} & $\begin{array}{l}\text { Indicator 1: The existence, structure and content of } \\
\text { the projective documents (development plan and im- } \\
\text { plementation plan). Aims, objectives and programs } \\
\text { established at the request of relevant stakeholders } \\
\text { are included in the development plan and in the } \\
\text { implementation plan. }\end{array}$ \\
\hline & & $\begin{array}{l}\text { Indicator 32: Setting up the school budget. The } \\
\text { school ensures the involvement of community part- } \\
\text { ners and relevant stakeholders in budget planning. }\end{array}$ \\
\hline & & $\begin{array}{l}\text { Indicator 34: Existence and implementation of in- } \\
\text { stitutional self-evaluation procedures. The self- } \\
\text { evaluation procedures are carried out with the par- } \\
\text { ticipation of relevant stakeholders. }\end{array}$ \\
\hline & \multirow{2}{*}{$\begin{array}{l}\text { Staff collaborate, learn } \\
\text { and exchange knowl- } \\
\text { edge with peers in other } \\
\text { schools through net- } \\
\text { works and/or school to- } \\
\text { school collaborations }\end{array}$} & $\begin{array}{l}\text { Indicator 30: Scientific activity of teachers. Teachers } \\
\text { capitalize on teaching the results of the scientific } \\
\text { research activity carried out at local, regional, na- } \\
\text { tional or international level. }\end{array}$ \\
\hline & & $\begin{array}{l}\text { Indicator 31: Methodological activity of teachers. } \\
\text { Teachers capitalize on teaching the results of the } \\
\text { methodological activities carried out at local level. }\end{array}$ \\
\hline
\end{tabular}

Notes Authors own development, based on the theoretical approach results on correlating the dimensions provided in the ofCD's (2016) and Kools and Stoll's (2017) sLo model and the performance indicators (including descriptors) for quality assessment and quality assurance in pre-university education provided in the Romanian Government Decision no. 1534 (Guvernul României 2008).

difference in the mean of the two sample values, internal and external evaluation, is not significantly different from zero); the $\mathrm{H} 1$ hypothesis (or the alternative hypothesis) - the values compared differ between them (in other words, the difference in the mean of the two sample values, internal and external evaluation, is significantly different from zero). In this way the reconciliation between the two evaluation processes (internal and external) can be considered and the results of the previous level of analysis can be validated.

\section{RESEARCH RESULTS}

Considering the previous quantitative scale (with points), were obtained average scores per indicator with values between 2 and 3 (table 2 presents the results of the first level of the analysis) and a gen- 
TAвLE 2 The Results of the First Level of the Analysis

\begin{tabular}{|c|c|c|c|}
\hline Performance indicators & (1) & $(2)$ & (3) \\
\hline $\begin{array}{l}\text { I01 The existence, the structure and the con- } \\
\text { tent of the projective documents (develop- } \\
\text { ment plan and implementation plan) }\end{array}$ & 2.550420 & 2.689076 & +0.138655 \\
\hline $\begin{array}{l}\text { I03 The existence and functioning of the in- } \\
\text { ternal and external communication system }\end{array}$ & 2.705882 & 2.705882 & 0.000000 \\
\hline I28 Evaluation of pupils' school results & 2.516807 & 2.676471 & +0.159664 \\
\hline I30 Scientific activity of teachers & 2.340336 & 2.361345 & +0.021008 \\
\hline I31 Methodological activity of teachers & 2.752101 & 2.726891 & -0.025210 \\
\hline I32 Setting up the school budget & 2.676471 & 2.726891 & +0.050420 \\
\hline $\begin{array}{l}\text { I34 Existence and implementation of institu- } \\
\text { tional self-evaluation procedures }\end{array}$ & 2.474790 & 2.500000 & +0.025210 \\
\hline I36 Professional development of staff & 2.630252 & 2.655462 & +0.025210 \\
\hline $\begin{array}{l}\text { I37 Revision of the educational offer and of } \\
\text { the development plan }\end{array}$ & 2.525210 & 2.630252 & +0.105042 \\
\hline I39 Teaching staff evaluation & 2.689076 & 2.710084 & +0.021008 \\
\hline
\end{tabular}

Notes Column headings are as follows: (1) average external assessment score, (2) average internal assessment score, (3) average score's differences (internal - external).

eral over-valuation tendency on the part of school organizations (for a single descriptor the two perspectives - external and internal - are identical). The average scores show that the performance is situated between 'good' and 'very good.'

Therefore, a second level of analysis is mandatory and the results of the bilateral parametric tests outlined in table 3 led to the identification of two indicators for which the values of the parameters belong to the critical region (therefore, in their case, the null hypothesis is rejected), there being a significant difference between the average of the evaluation internal results and the average of the external evaluation results. These differences were expected, reflecting a national reality:

1. For the indicator I01, the differences are determined by different perspectives regarding the projective documents: (a) the external assessment (objective) analyses the degree to which a school organization's plan is original (non-duplicated), adapted to the context in which it operates, responding to real community needs and realistic (having associated measurable indicators); (b) the internal assessment (subjective) is particularly concerned by the existence of the document itself (respecting a certain format), although the content (targets, indicators etc.) are 
TABLE 3 The Results of the Second Level of the Analysis

\begin{tabular}{lrrr}
\hline Performance indicators & $(1)$ & $(2)$ & $(3)$ \\
\hline $\begin{array}{l}\text { I01 The existence, the structure and the con- } \\
\text { tent of the projective documents (develop- }\end{array}$ & 0.390315 & 0.281477 & -2.60 \\
ment plan and implementation plan) & & & \\
I28 Evaluation of pupils' school results & 0.308541 & 0.294488 & -3.16 \\
I30 Scientific activity of teachers & 0.577449 & 0.449262 & -0.32 \\
I31 Methodological activity of teachers & 0.270479 & 0.257344 & 0.53 \\
I32 Setting up the school budget & 0.311295 & 0.307764 & -0.99 \\
I34 Existence and implementation of institu- & 0.375415 & 0.350840 & -0.45 \\
tional self-evaluation procedures & & & -0.51 \\
I36 Professional development of staff & 0.300261 & 0.276252 & -1.93 \\
I37 Revision of the educational offer and of & 0.392222 & 0.308665 & \\
the development plan & & & 0.43 \\
I39 Teaching staff evaluation & & & \\
\hline
\end{tabular}

Notes Column headings are as follows: (1) dispersion value in external evaluation, (2) dispersion value in internal evaluation, (3) test $z$ value. Authors own development using the significance threshold $\alpha=0.05$ and the critical region for the test $(-\infty ;-1.96) \cup[1.96 ; \infty)$.

not always realistic and/or adapted to the context in which the organization operates or the community it serves.

2. For the indicator 128 , the differences are determined by different perspectives regarding focus of the teaching path (design, realization, evaluation) on the development of the practical - applicative side of the competences, on the students (as subject of the educational approach) and on the learning outcomes: (a) the external assessment (objective) analyses insurance/failure to develop the practical-applicative side of the competences (starting from the design of the curriculum, continuing with its realization - the development of the didactic activities and ending with the assessment of the learning outcomes) and the systematic application/non-application of student-centered didactic methodologies; (b) the internal assessment (subjective) is particularly concerned by the designing of the new curriculum without taking into account that the overpopulation of certain student groups (as a result of the constant decrease of public expenditure in education) and the absence of new teaching practices (correlated with the new curricula) has led to an insufficient development of the practical - applicative side of competences, with effects on the participation rate and on the national exam results. 
TABLE 4 Number of Issues Tracked (Out of the Total Number of Issues Tracked by the National Standards) and Number of Schools That Have Fulfilled All of the Descriptors in National Standards

\begin{tabular}{lrr}
\hline Performance indicators & $(1)$ & $(2)$ \\
\hline $\begin{array}{l}\text { I03 The existence and functioning of the internal and } \\
\text { external communication system }\end{array}$ & 1, out of 2 & $171(71.84 \%)$ \\
I30 Scientific activity of teachers & 2, out of 2 & $110(46.21 \%)$ \\
I31 Methodological activity of teachers & 2, out of 2 & $174(73.10 \%)$ \\
I32 Setting up the school budget & 1, out of 2 & $171(71.84 \%)$ \\
I34 Existence and implementation of institutional & 2, out of 8 & $123(51.68 \%)$ \\
self-evaluation procedures & & \\
I36 Professional development of staff & 3, out of 4 & $158(66.38 \%)$ \\
I37 Revision of the educational offer and of the de- & 2, out of 2 & $73(30.67 \%)$ \\
velopment plan & & \\
I39 Teaching staff evaluation & 2, out of 4 & $171(71.84 \%)$ \\
\hline
\end{tabular}

NотеS Column headings are as follows: (1) number of tracked issues out of the total number of descriptors in national standards, (2) number of schools that have fulfilled all of the descriptors in national standards (percentage).

Consequently, due to the significant differences identified, these two performance indicators and their tracked descriptors were further excluded from the analysis.

However, it must be taken into account that in national standards each performance indicator has several subsequent descriptors and only some of them were find (at a theoretical level) as being correlated with key-characteristics of SLo's organizations. Therefore, at this time, with this kind of data and this type of analysis only the minimum level of incidence of the tracked issues can be determined, by calculating the percentage of schools that have met all the requirements (all descriptors), including those that are correlated with key-characteristics of suo's organizations. Table 4 presents for each performance indicator, the number of issues tracked by this research (out of the total number of issues tracked by the national standards) and the number of schools that have fulfilled all of the descriptors in national standards.

In this way, at sample level, the minimum levels of incidence of several key-characteristics of suo's were determined, these varying between $30.67 \%$ and $73.10 \%$ as can be seen in table 5 .

\section{Conclusion}

The experimental research is providing a preliminary overview on the state of affairs at the Romanian educational system level in relation to the model of sLo developed by Kools and Stoll (2017) and 
TABLE 5 The Minimum Levels of Incidence of Several Key-Characteristics of sLo's at Sample Level

\begin{tabular}{|c|c|c|}
\hline \multicolumn{2}{|c|}{ Dimension/characteristics } & \multirow{2}{*}{$\begin{array}{l}\text { Tracked issues (descriptors) in national standards } \\
\text { and the minimum level of incidence } \\
\text { Teachers participation in the scientific research } \\
\text { activity carried out by the school or at local, re- } \\
\text { gional, national or international level it has grown } \\
\text { in number and percentage }-46.21 \% \text {. }\end{array}$} \\
\hline 2nd & \multirow[t]{4}{*}{$\begin{array}{l}\text { Professional learning } \\
\text { connects work-based } \\
\text { learning and external ex- } \\
\text { pertise }\end{array}$} & \\
\hline & & $\begin{array}{l}\text { Teachers participation in the methodological } \\
\text { activities carried out at territorial level - with } \\
\text { demonstration activities, presentations etc. - it } \\
\text { has grown in number and percentage }-73.10 \% \text {. }\end{array}$ \\
\hline & & $\begin{array}{l}\text { The application in teaching activities of the par- } \\
\text { ticipation's results in continuous training and } \\
\text { professional development programs is systemat- } \\
\text { ically monitored }-66.38 \% \text {. }\end{array}$ \\
\hline & & $\begin{array}{l}\text { The application in teaching activities of the par- } \\
\text { ticipation's results in methodological and scien- } \\
\text { tific activities is systematically monitored }-66.38 \% \text {. }\end{array}$ \\
\hline & \multirow[t]{3}{*}{$\begin{array}{l}\text { Professional learning is } \\
\text { based on assessment and } \\
\text { feedback }\end{array}$} & $\begin{array}{l}\text { Observing the current activity and the feedback } \\
\text { received from the relevant beneficiaries are used } \\
\text { for the review of the professional development } \\
\text { plans }-66.38 \% \text {. }\end{array}$ \\
\hline & & $\begin{array}{l}\text { The assessment of the teaching staff is based on } \\
\text { feedback from relevant stakeholders and }-71.84 \% \text {. }\end{array}$ \\
\hline & & $\begin{array}{l}\text { The assessment of the teaching staff includes rec- } \\
\text { ommendations for further development }-71.84 \% \text {. }\end{array}$ \\
\hline \multirow[t]{3}{*}{$5^{\text {th }}$} & \multirow{2}{*}{$\begin{array}{l}\text { The school develop- } \\
\text { ment plan is evidence- } \\
\text { informed, based on } \\
\text { learning from self- } \\
\text { assessment, and updated } \\
\text { regularly }\end{array}$} & $\begin{array}{l}\text { The benchmarking is used to optimize the educa- } \\
\text { tional offer and the development plan }-30.67 \% \text {. }\end{array}$ \\
\hline & & $\begin{array}{l}\text { The staff and relevant stakeholders are involved } \\
\text { in reviewing the educational offer and the devel- } \\
\text { opment plan }-30.67 \% \text {. }\end{array}$ \\
\hline & $\begin{array}{l}\text { The school regularly } \\
\text { evaluates its theories of } \\
\text { action, amending and up- } \\
\text { dating them as necessary }\end{array}$ & $\begin{array}{l}\text { The results of self-evaluation and external eval- } \\
\text { uation are used to plan, carry out and review the } \\
\text { quality assurance and improvement activities and } \\
\text { procedures }-51.68 \% \text {. }\end{array}$ \\
\hline
\end{tabular}

Continued on the next page

with the key-characteristics (key features) provided by 'What Makes a School a Learning Organisation? A Guide for Policy Makers, School Leaders and Teachers' document (OECD 2016).

From an experimental point of view, resulted that the minimum levels of incidence of several key-characteristics of suo's could be identified, these varying between $30.67 \%$ and $73.10 \%$, but only for three action-oriented dimensions - 'creating and supporting contin- 
TABLE 5 Continued from the previous page

\begin{tabular}{lll}
\hline Dimension/characteristics & $\begin{array}{l}\text { Tracked issues (descriptors) in national standards } \\
\text { and the minimum level of incidence }\end{array}$ \\
\hline 6th & $\begin{array}{l}\text { The school is an open } \\
\text { system, welcoming ap- } \\
\text { proaches from potential } \\
\text { external collaborators }\end{array}$ & $\begin{array}{l}\text { The school systematically communicates with } \\
\text { parents and other stakeholders }-71.84 \% .\end{array}$ \\
\hline $\begin{array}{l}\text { The school collaborates } \\
\text { with parents/guardians }\end{array}$ & $\begin{array}{l}\text { The school ensures the involvement of commu- } \\
\text { nity partners and relevant stakeholders in budget } \\
\text { and the community as } \\
\text { partners in the education } \\
\text { process and the organiza- } \\
\text { tion of the school }\end{array}$ & $\begin{array}{l}\text { The self-evaluation procedures are carried out } \\
\text { with the participation of relevant stakeholders - }\end{array}$ \\
\hline $\begin{array}{l}\text { Staff collaborate, learn } \\
\text { and exchange knowl- } \\
\text { edge with peers in other } \\
\text { schools through networks } \\
\text { and/or school to-school }\end{array}$ & $\begin{array}{l}\text { Teachers capitalize on teaching the results of the } \\
\text { scientific research activity carried out at local, re- } \\
\text { gional, national or international level -46.21\%. }\end{array}$ & $\begin{array}{l}\text { Teachers capitalize on teaching the results of the } \\
\text { methodological activities carried out at local level } \\
\text { collaborations }\end{array}$ \\
\hline
\end{tabular}

uous learning opportunities for all staff,' 'embedding systems for collecting and exchanging knowledge and learning' and 'learning with and from the external environment and larger learning system.' At this point, it cannot be determined whether these schools act fully or not as learning organizations, but the results demonstrate that in some respects they develop key features of sLo; and this may be the foundation for a smooth implementation of the model at national level.

The limitation of this paper is given by the fact that the data were collected from the external and internal evaluation of 238 schools (in order to determine the level of educational services offered), means not specifically devoted to identifying sLo characteristics. However, another in-depth analysis, staff dedicated and focused on all actionoriented 'dimensions' is scheduled and will be provided in the next period.

\section{References}

Bordeianu, O., C. V. Hapenciuc, R. Bejinaru, and A. Burciu. 2014. 'Dimensions of the Learning Organization within Pharmaceutical Companies in Romania.' Paper presented at the 8th International Management Conference Management Challenges for Sustainable Development, Bucharest, Romania, 6-7 November.

Garvin, D. A., A. C. Edmondson, and F. Gino. 2008. 'Is Yours a Learning Organization?' Harvard Business Review 86 (3): 109-16. 
Giura, D. (2012). 'Learning Organisations: Un studiu exploratoriu asupra Consiliilor Judeţene din România.' Revista Transilvană de Ştiinţe Administrative 2 (31): 33-46.

Guvernul României. 2008. 'Hotarare privind aprobarea standardelor de referinta si a indicatorilor de performanta pentru evaluarea si asigurarea calitatii in invatamantul preuniversitar.' Monitorul oficial al Romaniei, no. 822.

Paraschiva, G. A., Z. B. Farkas, A. Jitarel, and A. Draghici. 2018. 'A Study of the Evolution of Educational Efficiency: Romanian Case.' In Integrated Economy and Society: Diversity, Creativity, and Technology Proceedings of the MakeLearn and тіп International Conference, edited by V. Dermol, 463-70. Bangkok, Celje, Lublin: ToKnowPress.

Kools, M., and L. Stoll. 2017. 'What Makes a School a Learning Organisation?' Education Working Paper No. 137, OECD, Paris.

oEcD. 2016. What Makes a School a Learning Organisation? A Guide for Policy Makers, School Leaders and Teachers. Paris: ozcD.

Sarder, R. 2016. Building an Innovative Learning Organization: A Framework to Build a Smarter Workforce, Adapt to Change, and Drive Growth. Hoboken, NJ: Wiley.

Senge, P. M. 1990. The Fifth Discipline: The Art and Practice of the Learning Organization. New York: Wiley.

Watkins, K. E., and V. J. Marsick. 1993. Sculpting the Learning Organization: Lessons in the Art and Science of Systemic Change. San Francisco, cA: Jossey-Bass.

This paper is published under the terms of the Attribution-

NonCommercial-NoDerivatives 4.0 International (CC BY-NC-ND 4.0)

License (http://creativecommons.org/licenses/by-nc-nd/4.o/). 